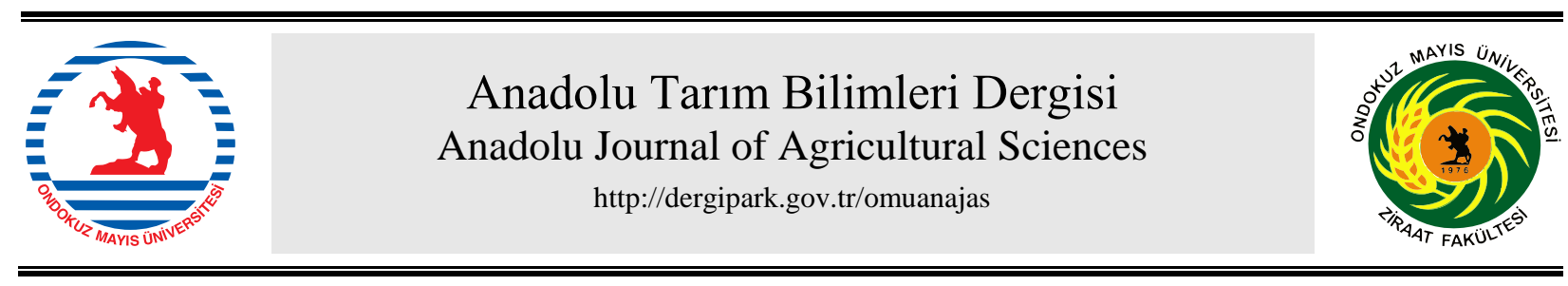

Araştırma/Research

Anadolu Tarım Bilim. Derg./Anadolu J Agr Sci, 34 (2019)

ISSN: 1308-8750 (Print) 1308-8769 (Online)

doi: 10.7161/omuanajas. 458988

\title{
Tarımsal sulamaların ekonomik ve sosyal etkilerinin değerlendirilmesi: Asartepe Barajı üzerine bir uygulama
}

\author{
Mehmet Arif Şahinli, Ahmet Özçelik \\ Ankara Üniversitesi, Ziraat Fakültesi, Tarım Ekonomisi Bölümü, Ankara/Türkiye \\ *Sorumlu yazar/corresponding author: asahinli@ ankara.edu.tr
}

Geliş/Received 11/09/2018～Kabul/Accepted 30/05/2019

\begin{abstract}
ÖZET
Araştırma alanı, Ankara ili Ayaş ilçesinde bulunan Asartepe Barajı sulama sahasıdır. Bu çalışmada, baraj yapımının tarımsal sulamada ve üretim deseninde ne tür değişiklikler ortaya çıkardığı amaçlanmıştır. Tarım işletmelerine ait veriler 2016 yılı üretim dönemine aittir. Bu çalışmada, araştırma bulguları ve ikincil verilerden de yararlanılmıştır. Araştırma alanında örneğe giren köyleri en iyi temsil edecek 3 köy seçilmiştir. Araştırmada örnek hacminin belirlenmesinde $\% 5$ hata ve $\% 95$ güven düzeyinde çalışılmıştır. Örnek hacmi 42 işletme olarak tespit edilmiştir. Bitkisel ürünlerde maliyet hesabı üründen ürüne farklılık göstermektedir. Aynı zamanda bitkilerin tek yıllık ve çok yıllık oluşu da önemlidir. Gruplara göre $1 \mathrm{~kg}$ domates maliyet hesapları yapılmıştır. İncelenen işletmelerde 1. gruptaki üreticilerin $1 \mathrm{~kg}$ domates maliyeti $0.54 \mathrm{TL}$ iken 2. grupta olanların $0.50 \mathrm{TL}$ olarak hesaplanmıştır.

Baraj öncesinde 1. gruptaki işletmelerin sulu arazi genişliği ortalama 14.0 dekar iken baraj sonrasında ortalama 25.5 dekara, 2. gruptaki üreticilerde ise sulu arazi genişliği 25.5 dekardan 58.1 dekara yükselmiştir. İncelenen işletmelerdeki alet- makine sayılarında artış gözlenmiştir. İncelenen işletmelerde baraj yapımının tarımsal sulamanın kullanımının etkinliğini arttırmasının yanı sıra üreticilerin üretim deseninde de değişikliğe gittiği tespit edilmiştir.
\end{abstract}

Evaluation of economic and social effects of agricultural 1rrigations: An application on Asartepe Dam

\section{ABSTRACT}

The Asartepe Dam irrigation area in Ayaş county of Ankara province was a research area. In this study, it is aimed to determine what kind of changes the dam construction has in agricultural irrigation and production pattern. Data for agricultural enterprises are 2016 year production period. Research findings and secondary data are used in this study. In the research area, the 3 best villages were selected. In the study, with $5 \%$ error and $95 \%$ confidence level for determining the sample size was used. The sampling volume was determined as 42 enterprises. The cost calculation in plant products vary from product to product. It is also important to have a one-year and multi-year plants. According to the groups, the cost of producing of $1 \mathrm{~kg}$ tomato was calculated. In the examined enterprises, the cost of 1 $\mathrm{kg}$ of producing tomatoes by the producers in the 1 st group was $0.54 \mathrm{TL}$ (Turkish Lira), while those in the second group was $0.50 \mathrm{TL}$.

Before the dam, the average area of the irrigated land in the establishments of first group was 14.0 decares, an average of 25.5 decares after the dam while in the 2nd group the irrigated land width increased from 25.5 to 58.1 decares. There was an increase in the number of machinery usage in the enterprises examined. In the enterprises surveyed, the production of dam has improved the efficiency of the use of agricultural irrigation, as well as the production pattern of the producers.

Anahtar Sözcükler: Tarımsal sulama Ankara ili Ayaş ilçesi Maliyet hesapları

\section{Giriş}

Ankara'nın alt bölgelerinden Birinci Bölge; Bala, Evren, Haymana ve Şereflikoçhisar ilçelerini kapsamaktadır. Nüfus yoğunluğunun düşük, tarımın ekonomik faaliyetlerin temelini oluşturduğu bu bölge Ankara ilinin güney ve güneydoğu kesimlerini kapsamaktadır. Ayrıca ilin en yüksek güneş enerjisi potansiyeline sahip olan bu bölgede gelecek on yilda gerçekleştirilecek güneşe dayalı elektrik üretim 
yatırımları, çevresel katkısının yanında, tarımsal sulamanın yaygınlaştırılmasında ve maliyetinin düşürülmesinde de etkili olacaktır. Ankara'nın kuzeydoğusunda yer alan 2. Bölge Çubuk ve Kalecik ilçelerinden oluşmaktadır. Sulu tarımın yaygın olduğu bölgede tahıl üretiminin yanında, meyve-sebze üretimi ve hayvancılık ile tarıma dayalı sanayi de gelişmiştir (Ankaraka, 2015).

Ankara'nın kuzeyinde bulunan Üçüncü Bölge Kızılcahamam ve Çamlıdere ilçelerinden oluşmaktadır. İlin büyük çoğunluğundan farklı olarak bölge yoğun ormanlara ve zengin su kaynaklarına sahiptir. Ankara'nın önemli içme suyu kaynakları olan Çamlıdere, Eğrekkaya, Kurtboğazı ve Akyar barajları bu bölgede yer almaktadır. Kuzeybatı Ankara'yı kapsayan Dördüncü Bölge Ayaş, Beypazarı, Güdül ve Nallıhan ilçelerinden oluşmaktadır. Tarım alanında da güçlü olan bölge, özellikle meyve ve sebze üretiminde öne çıkmaktadır. Bunlara ilaveten bölgede büyük ölçekli ve stratejik öneme sahip sanayi yatırımları bulunmaktadır. Bölgedeki termik ve hidroelektrik santraller Ankara'nın kurulu elektrik gücünün \%44'üne sahiptir (Ankaraka, 2015).

Akyurt, Elmadă̆, Kazan ve Polatll'dan oluşan Beşinci Bölge Ankara'nın metropolitan alanını çevrelemektedir. Bölgenin temel karakteristiği, diğer alt bölgelere benzer şekilde sahip olduğu tarımsal üretimin yanı sıra, güçlü bir sanayi altyapısının bulunmasıdır. 2012 y1lı itibariyle Altındağ, Çankaya, Etimesgut, Gölbaşı, Keçiören, Mamak, Pursaklar, Sincan ve Yenimahalle'den oluşan Ankara Merkez Bölgesi, Ankara nüfusunun \%89'una ev sahipliği yapmaktadır (Ankaraka, 2015).

$\mathrm{Bu}$ çalışmayla, sulama projeleri ile DSİ tarafindan uygulanan küçük ve büyük ölçekli sulama projelerinin Ankara ili ve Türkiye ölçeğinde sosyal ve ekonomik etkileri ve katkılarının kapsamlı bir şekilde araştırılması ve gelecekte yapılacak benzer yatırımlar için öneriler geliştirilmesi amaçlanmaktadır.

Asartepe Barajı, Ankara ili Ayaş ilçesi, İlhan Çayı üzerinde, Çanıllı Beldesi sınırları içerisinde, sulama amacı ile 1975-1980 yılları arasında inşa edilmiş bir barajdır. Toprak gövde dolgu tipi olan barajın gövde hacmi $408.000 \mathrm{~m} 3$, akarsu yatağından yüksekliği 50,00 metre, normal su kotunda göl hacmi $20 \mathrm{hm} 3$, normal su kotunda göl alanı 1,77 km2'dir. 2.850 hektarlık bir alana sulama hizmeti vermektedir.

Sulama ile ilgili yapılmış ulusal ve uluslararası çalışmalardan bazıları aşağıda verilmiştir:

Mudima (2002) çalışmasında, K. Zimbabwe'de beş adet küçük sulama sisteminin etkisini incelemiştir. Büyükcangaz (2003) ise, mevcut sulama projelerinin çevresel etkilerinin belirlenmesi ve değerlendirilmesinden yola çıkarak, Çevresel etki değerlendirmesi (ÇED)'de gerçekçi yaklaşımlara ulaşılması hedeflenmiş, sulama projeleri ile çevrede meydana gelebilecek etkiler materyal olarak alınan Mustafa Kemal Paşa Sulama Projesi (MKPSP) kapsamında değerlendirmiştir. Doak et al. (2004) çalışmalarında, 2002/2003 milli ekonomide mevcut sulamanın katkısını hesaplamıştır. Koç ve Güner (2005) çalışmasında, Türkiye'de geçmiş yıllarda yapılmış olan sulama projelerinin Birleşmiş Milletler Gıda ve Tarım Organizasyonu (FAO) tarafindan önerilen kriterlere göre yeniden hesaplanması durumunda nasıl değişiklikler olacağını incelemiştir. Yıldırım (2006) ise, 1990'lardan itibaren Dicle ve Firat Nehirleri üzerinde faaliyete geçen barajların enerji ve sulama gibi ekonomik faydaları yanında bazı doğal çevre etkilerini incelemiştir. Özkay ve ark. (2008) çalışmalarında, sulama projelerinin çevreye olan olumsuz etkilerinin azaltılmasına yönelik alınması gerekli önlemleri tartışmıştır. Çakmak vd. (2009) çalışmalarında, Türkiye'de Asartepe Sulama Birliğinde sulama sistem performansını değerlendirmişlerdir. Kaltu ve Güneş (2010) çalışmalarında, Orta Anadolu ve özellikle Ankara koşullarında hem yem ve hem de yağ bitkisi olarak yetiştiriciliği artan mısırda, farklı sulama şekillerinde üretim maliyeti, verimlilik ve karlılık düzeyini araştırmıştır. Sönmez (2011) çalışmasında, Türkiye'de sulama ve enerji amaçlı önemli ölçüde faydalanılan kaynakların başında gelen barajlar, tarım alanlarının daralması, siltasyon, ekosistemin bozulması ve göçler gibi birçok sorunu incelemiştir. Saunders and Saunders (2012) çalışmalarında, Cantenbury'de sulamanın toplam faydasının incelenmesi aynı zamanda Canterbury su stratejisinin yürütülmesini amaçlamıştır. Demir vd. (2014) çalışmalarında, Daphan Ovası sulama alanında, sulama işletmeciliği açısından mevcut durumu incelemiş ve yapılan sulama yatırımının tarımsal üretime etkisini ortaya koymaya çalışmıştır.

2016 yılında ekimi en fazla yapilan sebzelerden birinci sırada yer alanların oranı \%42.03 ile kavun, ikinci sirada \%19.87 ile sofralık domates ve \%9.55 ile kuru soğan olmuştur. Domates, Ayaş ilçesinde önemli bir sebze olduğundan sulama öncesi ve sonrası maliyet hesaplamaları yapılmıştır.

\section{Materyal ve Yöntem}

Araştırma kapsamında, Ankara ili Ayaş ilçesinde domates yetiştiriciliğine yer veren tarım işletmelerinden Asartepe barajından yapılan tarımsal sulamaların öncesine ve sonrasına ait veriler anket ile toplanmıştır. Tarım işletmelerinden 2016 üretim dönemine ait veriler toplanmıştır. Araştırmada uygulanan metotlar aşağıda verilmektedir.

\section{1. Örnek seçiminde uygulanan yöntem}

Tarımsal sulama yapan tarım işletmeleri popülasyonunu belirlemek amacıyla, Ankara ili Ayaş İlçesi Gıda, Tarım ve Hayvancılık İlçe Müdürlüğü yetkilileri ile ön görüşmeler yapılmıştır. Örnek köyler seçilirken, doğal faktörler, tarım tekniği ve ekonomik durum bakımından araştırma alanını temsil etmesine dikkat edilmiştir. Araştırma kümesi belirlendikten sonra anket uygulanacak işletmeler tesadüfi örnekleme 
yöntemiyle saptanmıştır. Tarımsal sulama yapan işletmelerin oluşturacağ 1 kümelerin kaç gruba ayrılacağına, araştırma kümesi belirlendikten sonra karar verilmiştir. Köylerde anket yapılacak örneğe çıkan işletmeciler bulunmadığı durumlarda ikameleri belirlenmiş ve bunun için yedek işletme listesi oluşturulmuştur.

Araştırmanın amacına uygun olarak hazırlanmış anket formları, araştırıcılar tarafindan kişisel görüşme yoluyla doldurulmuştur. Böylece analize esas teşkil edecek birincil veriler doğrudan doğruya örneğe çıkan çiftçi ailelerinden elde edilmiştir. İkincil veriler ise, konuya ilişkin literatür ve istatistiklerden yararlanılarak temin edilmiştir.

Örneğe giren köyleri en iyi temsil edecek 3 köy belirlenmiş̧ir. Elde edilen veriler neticesinde 3 köyde amaca uygun olarak 42 işletme tespit edilmiştir. Toplam işletme sayıları belirlenmiş ve araştırma alanındaki işletmelerin arazi dağılımı da dikkate alınmıştır. Sonuç olarak, işletmeler arazi büyüklükleri bakımından iki tabakaya ayrılmıştır. Tabaka sınırları 1-20 dekar ve 20-+ dekar olarak belirlenmiştir. Neyman paylaştırma metoduna göre, tabakaların sayıları belirlenmiştir (Çizelge 1).

\section{Çizelge 1. İşletmelerin tabakalara göre örneklem sayıları}

\begin{tabular}{lcc}
\hline Tabaka & Genişlik & İşletme sayısı \\
1 & $1-20$ & 31 \\
2 & $20+$ & 11 \\
Toplam & & 42 \\
\hline
\end{tabular}

J. Neyman tarafindan 1934 yılında önerilen bir metottur ve genel itibariyle Neyman paylaştırması adı diye isimlendirilir. Farklı tabakalara ilişkin c_h maliyetleri birbirinden büyük farklılık arz etmeyebilir ve bu nedenden dolayı bütün tabakalar için $\mathrm{c}$ h h ların eşit olabileceği varsayabilir. Örnek sayısı,

$$
n=\frac{\left(\sum N_{h} S_{h}\right)^{2}}{N^{2} * D^{2}+\sum N_{h} S_{h}^{2}}
$$

Burada; n örnek sayısını; Nh h'ıncı tabakadaki işletme sayısını; Sh h'ıncı tabakanın standart sapmasını; Sh2 h'ınc1 tabakanın varyansını; N Popülasyondaki işletme sayısını göstermektedir. D2 ise $(\mathrm{d} / \mathrm{z}) 2$ formülü ile elde edilir.

$\mathrm{Bu}$ durum çapı $\mathrm{n}$ olan bir örneğin $\mathrm{N} \_\mathrm{h} \mathrm{S}$. $\mathrm{h}$ ile orantılı bir şekilde paylaştırıldığını gösterir. Bu ise, büyük tabaka ve heterojen bir tabakadan daha fazla örnek biriminin alınacağını ifade eder (Yamane, 2001).

\subsection{Anket ve analiz aşamasinda uygulanan yöntem}

Araştırmanın amacı, kapsamı ve tarım işletmelerinin özellikleri de göz önünde bulundurularak anket formları düzenlenmiştir. Anket formları, işletme sahipleri ile görüşme yöntemi ile araştırıcı tarafından doldurulmuştur. İşletme sonuçlarının analiz ve değerlendirme aşamasında, tarım işletmeleri bir bütünlük içerisinde ele alınmıştır. Analiz aşamasında, SPSS İstatistik paket programı kullanılmıştır.

Araştırma kapsamında incelenen işletmelerde, domates birim $(\mathrm{kg})$ maliyetleri belirlenmiştir. Domates birim maliyeti her işletme grubunun verileri dikkate alınarak ayrı ayrı hesaplanmıştır.

Domates üretim faaliyetinde toprak hazırlığ masrafları, 1. Sürüm, 2. Sürüm, ekim ve dikim işlemleri sirasında yapılan faaliyetlerin masraflarından oluşmaktadır. Toprak hazırlığı işlemlerinde kullanılan makine masrafları, toplam domates ekim alanı için tükettiği akaryakıt miktarı ile birim fiyatlar dikkate alınarak hesaplanmıştır. İnsan iş gücü masrafları ise, toplam ekim alanı için kullanılan erkek iş gücü saatleri ile bölgede geçerli olan iş̧̧i saat ücreti çarpılarak belirlenmiştir.

Ekim işleminde kullanılan tohum ve gübre miktarları birim fiyatlar üzerinden hesaplanarak masraf olarak yazılmıştır.

Bakım işlemleri gübreleme, çapalama, ilaçlama ve sulama masraflarından oluşmaktadır. Gübreleme masrafi, toplam domates ekim alanı için kullanılan gübre bedeli, gübreleme işçiliği ve alet makine masraflarından oluşmaktadır. Gübreleme masraflarında insan iş gücü ücreti ve makine çekigücü ücreti hesaplandıktan sonra, gübrelemenin üç defa uygulandığı dikkate alınarak hesaplama yapılmıştır.

Çapalama masrafi, çapalama için kullanılan erkek iş gücü saatleri ile bölgede geçerli olan işçi-saat ücreti çarpılarak hesaplanmıştır.

İlaçlama masrafi, toplam domates ekim alanı için kullanılan tarımsal mücadele ilaç bedeli, ilaçlama işçiliği ve alet makine masraflarından oluşmaktadır.

Sulama masrafları, sulama işçiliği ve su parası bedelinin toplamından oluşmaktadır.

Hasat masrafi, hasat için kullanılan erkek iş gücü saatleri ile bölgede geçerli olan işçi saat ücreti çarpılarak hesaplanmıştır.

Paketleme masrafi, ürünün paketlenmesi aşamasında kullanılan erkek iş gücü saatleri ile bölgede geçerli olan işçi saat ücreti çarpılarak hesaplanmıştır.

Pazara taşıma masrafı domatesin ambardan satış yerine kadar olan nakliye masraflarında oluşmaktadır.

Arazi kirası hesaplanmasında, arazi fiilen kiralanmış ise ödenen kira bedeli, kendi mülkü ise bölgedeki benzer nitelikteki araziler için oluşmuş cari arazi kirası dikkate alınmıştır.

Domates üretim faaliyetinde değişen masrafların toplamının \%3'ü kadar genel idare gider hesaplanmıştır.

Domates maliyetinin hesaplanmasında değişen ve sabit masrafların toplamı, üretim masrafları olarak değerlendirilmektedir. $\mathrm{Bu}$ değerin, elde edilen domates miktarına bölünmesiyle $1 \mathrm{~kg}$ domates maliyeti hesaplanmıştır. 


\section{Bulgular ve Tartışma}

\subsection{Nüfus Durumu}

Ankete katılan işletmelerde hanehalkının \%49.59'u 15-49 yaş aralığında, \%39.02'si ise 50 yaş ve üzerindedir. Erkek nüfusunun \%45.16'sı 50 yaş ve üzerinde iken kadın nüfusunun \%57.38'si 15-49 yaş aralığındadır ve erkek nüfusuna oranla daha genç bir nüfusa sahiptir (Çizelge 2).

Araştırma bölgesinde genel olarak domates yetiştiriciliği yapılmaktadır. Sebze ekim, bakım ve hasat da genellikle kadın işçiler çalıştırılmaktadır. Kadın nüfusunun daha genç olması bu nedenle beklenilen bir durumdur.

\section{2. Ĕ̈itim Durumu}

Araştırma kapsamında incelenen işletmelerde üreticilerin eğitim durumu Çizelge 3'de belirtilmiştir.

Üreticilerin \%73.81'inin ilkokul mezunu olduğu belirlenirken, \%16.67'si ortaokul, \%4.76's1 lise ve \%4.76'sı üniversite mezunudur. Ayaş ilçesi, Ankara iline yakın olduğundan tahsilli bireylerin ilçeden göç ettikleri ifade edilebilir (Çizelge 3).

Çizelge 2. İncelenen işletmelerde hanehalkı durumu

\begin{tabular}{llcccccccc}
\hline \multirow{5}{*}{ Erkek } & \multicolumn{2}{c}{$7-14$} & \multicolumn{2}{c}{$15-49$} & \multicolumn{2}{c}{$50-+$} & \multicolumn{2}{c}{ Toplam } \\
\cline { 3 - 9 } & & Say1 & $\%$ & Say1 & $\%$ & Say1 & $\%$ & Say1 & $\%$ \\
& 1. Grup & 6 & 12.77 & 20 & 42.55 & 21 & 44.68 & 47 & 100.00 \\
& 2. Grup & 2 & 13.33 & 6 & 40.00 & 7 & 46.67 & 15 & 100.00 \\
& Toplam & 8 & 12.90 & 26 & 41.94 & 28 & 45.16 & 62 & 100.00 \\
\multirow{3}{*}{ Kadin } & 1. Grup & 5 & 10.87 & 24 & 52.17 & 17 & 36.96 & 46 & 100.00 \\
& 2. Grup & 1 & 6.67 & 11 & 73.33 & 3 & 20.00 & 15 & 100.00 \\
& Toplam & 6 & 9.84 & 35 & 57.38 & 20 & 32.79 & 61 & 100.00 \\
& Genel Toplam & 14 & 11,38 & 61 & 49.59 & 48 & 39.02 & 123 & 100.00 \\
\hline
\end{tabular}

Çizelge 3. İncelenen işletmelerde üreticilerin eğitim durumu

\begin{tabular}{|c|c|c|c|c|c|c|c|c|c|c|}
\hline & \multicolumn{2}{|c|}{ İlkokul } & \multicolumn{2}{|c|}{ Ortaokul } & \multicolumn{2}{|r|}{ Lise } & \multicolumn{2}{|c|}{ Üniversite } & \multicolumn{2}{|c|}{ Toplam } \\
\hline & $\mathrm{n}$ & $\%$ & $\mathrm{n}$ & $\%$ & $\mathrm{n}$ & $\%$ & $\mathrm{n}$ & $\%$ & $\mathrm{n}$ & $\%$ \\
\hline 1. Grup & 23 & 74.19 & 5 & 16.13 & 1 & 3.23 & 2 & 6.45 & 31 & 100.00 \\
\hline 2. Grup & 8 & 72.73 & 2 & 18.18 & 1 & 9.09 & 0 & 0.00 & 11 & 100.00 \\
\hline Toplam & 31 & 73.81 & 7 & 16.67 & 2 & 4.76 & 2 & 4.76 & 42 & 100.00 \\
\hline
\end{tabular}

\subsection{Arazi Varlı̆ğ}

İşletmelerin arazi tasarruf şekillerine göre dağılımı Çizelge 4'de gösterilmiştir. Baraj yapımından önce 1 . gruptaki işletmelerin ortalama mülk arazisi 35.84 dekar iken barajdan sonra 44.33 dekara yükselmiştir. 2 . gruptaki üreticilerde ise barajdan önce 49.87 dekar olan mülk arazisi, barajdan sonra 55.04 dekara yükselmiştir. Arazinin sulanması ve veriminin artmasiyla birlikte tarımda kullanılan arazi miktarında da bir yükselme ortaya çıkmıştır (Çizelge 4).

Baraj yapımından sonra kiraya tutulan arazi miktarlarında daha büyük artış yaşanmış olup, 1 . gruptaki üreticilerin ortalama kiraya tutulan arazi miktarı 28.16 dekardan 53.07 dekara, 2. gruptaki üreticilerde ise 46.03 dekardan 69.36 dekara yükselmiştir (Çizelge 4).

Çizelge 4. İncelenen işletmelerin arazi tasarruf şekillerine göre dağılımı

\begin{tabular}{llcccccc}
\hline & \multicolumn{2}{c}{ Mülk arazi } & \multicolumn{2}{c}{ Kiraya tutulan arazi } & \multicolumn{2}{c}{ Toplam } \\
\cline { 3 - 7 } & & $\mathrm{da}$ & $\%$ & $\mathrm{da}$ & $\%$ & $\mathrm{da}$ & $\%$ \\
\multirow{3}{*}{ Öncesi } & 1. Grup & 35.84 & 56.00 & 28.16 & 44.00 & 64.00 & 100.00 \\
& 2. Grup & 49.87 & 52.00 & 46.03 & 48.00 & 95.90 & 100.00 \\
\multirow{3}{*}{ Sonras1 } & 1. Grup & 44.33 & 45.51 & 53.07 & 54.49 & 97.40 & 100.00 \\
& 2. Grup & 55.04 & 44.24 & 69.36 & 55.76 & 124.40 & 100.00 \\
\hline
\end{tabular}


Araştırma kapsamında incelenen bölgede baraj yapımından sonra arazilerin sulama olanağının artması beklenebilir bir sonuçtur. $\mathrm{Bu}$ bağlamda araştırma sonuçlarını incelendiğinde, 1 . gruptaki üreticilerin ortalama sulu arazisi 14.0 dekardan 45.2 dekara, 2. grupta ise 25.5 dekardan 58.1 dekara yükseldiği tespit edilmiştir. (Çizelge 5).

(Demir ve ark., 2014) yılında, Daphan ovası sulama projesi ile birlikte 2000 y1lında 16,21 dekar olan sulanan arazi genişliğinin, 2013 yılında 62,33 dekara yükseldiğini belirtmişlerdir.

Çizelge 5. İncelenen işletmelerde arazinin nevine göre dağılımı

\begin{tabular}{|c|c|c|c|c|c|c|c|c|c|c|c|}
\hline \multirow[b]{4}{*}{ Öncesi } & \multirow{3}{*}{ 1. Grup } & \multicolumn{2}{|c|}{ Sulu } & \multicolumn{2}{|c|}{ Kuru } & \multicolumn{2}{|c|}{ Sebzelik } & \multicolumn{2}{|c|}{ Meyvelik } & \multicolumn{2}{|c|}{ Toplam } \\
\hline & & da & $\%$ & $\mathrm{da}$ & $\%$ & $\mathrm{da}$ & $\%$ & $\mathrm{da}$ & $\%$ & da & $\%$ \\
\hline & & 14.0 & 21.8 & 30.4 & 47.5 & 13.1 & 20.5 & 6.5 & 10.2 & 64.00 & 100.0 \\
\hline & 2. Grup & 25.5 & 26.6 & 48.0 & 50.1 & 5.4 & 5.6 & 17.0 & 17.7 & 95.90 & 100.0 \\
\hline \multirow[b]{2}{*}{ Sonras1 } & 1. Grup & 45.2 & 46.4 & 28.2 & 28.9 & 16.2 & 16.6 & 7.8 & 8.0 & 97.40 & 100.0 \\
\hline & 2. Grup & 58.1 & 46.7 & 43.6 & 35.1 & 11.3 & 9.1 & 11.4 & 9.2 & 124.40 & 100.0 \\
\hline
\end{tabular}

Araştırma yöresinde arazi nevi içerisinde tarla arazisi hakim derecede olup, işletme arazisinin baraj yapımı öncesi 1 . grupta $\% 21.88$ 'i sulu \%47.50'si kuru olmak üzere \%69.38'ini, 2. grupta ise \%26.59'u sulu, $\% 50.05$ 'i kuru \%76.64'ünü oluşturmaktadır. Baraj yapım1 sonras1 1. grupta sulu tarla oran1 \%46.41'e, 2. grupta bu oran \%46.70'e çıkarken kuru tarla arazisi oranında düşüş görülmektedir. Sebzelik arazi 2. grupta sulama sonrası artmış, meyvelik arazide ise 1. grupta artı̧̧ olmuştur. Sulama sonrası, arazi nevi olarak tarla arazisindeki artışın temel sebebi hayvancıllı̆̆ı artışına paralel olarak yem bitkisi (arpa, yonca, fiğ, yulaf) miktarının artmasıdır (Çizelge 5).

\subsection{Bitkisel Üretim}

Araştırma bölgesi olarak belirlenen Ankara ili Ayaş ilçesinde domates üretiminin yoğunlukta olduğu bilinmektedir. 1. gruptaki üreticilerin domates ekim alanı baraj öncesi ortalama 8.2 dekar iken bu rakam baraj sonrasında 5.8 dekara, aynı zamanda nadas alanı da 14.3 dekardan 4.6 dekara gerilediği tespit edilmiştir. Baraj yapımından sonra ise sulama imkânının da artmasıyla birlikte üretim deseninde değişiklikler göze çarpmaktadır. Arpa üretimi 3.2 dekardan 10.4 dekara, yulaf üretimi 2.3 dekardan 7.9 dekara, fiğ üretimi 4.6 dekardan 8.8 dekara, yonca üretimi 2.5 dekardan 10.7 dekara yükselmiştir. Ayrıca, mısır üretiminin de baraj öncesi yapılmazken baraj sonrasında 4.2 dekara yükseldiği belirlenmiştir (Çizelge 6).

Araştırma kapsamındaki 2. gruptaki üreticilerin üretim deseninde de değişiklikler göze çarpmaktadır. Baraj öncesi domates ekim alanı 38.2 dekar olan 2. gruptaki üreticilerin, baraj sonrasında domates ekim alanı 30.4 dekara, nadas alanı 8.1 dekardan 3.4 dekara gerilemiştir. Bununla birlikte, ekim alanı buğday için
7.1 dekardan 10.2 dekara, arpa için 7.3 dekardan 12.8 dekara, yulaf için 1.2 dekardan 8.4 dekara, mısır için 3.0 dekardan 6.1 dekara, yonca için 4.2 dekardan 10.5 dekara, biber için 4.6 dekardan 6.6 dekara çıkmıştır. Ayrıca, fiğ ekimi baraj öncesinde hiç yapılmazken baraj sonrasında 10.5 dekara yükseldiği tespit edilmiştir (Çizelge 6). Bu durumun sebebi olarak, domates üretiminde verimin yeterli seviye de olmaması ve ürün satışı konusunda yaşanan sıkıntılar olarak belirtilebilir.

(Büyükcangaz, 2003) yılında, Mustafa Kemalpaşa sulama projesinde, projenin uygulamaya geçirilmesinden önce, ovada görülen bitki deseninin; \%48.5'nin hububat, \%8.0'nin pancar, \%8.5'nin ayçiçeği, \%6.0'nın pamuk ve \%26.0'nın diğer ürünler biçiminde olduğunu ifade etmiştir. Sulama projesinin uygulamaya geçirilmesine paralel olarak, ovada bitki deseninin tümüyle değiştiğini ifade etmiştir.

Başka bir çalışmada ise, sulama öncesi yem bitkileri ekim alanı \%51.7 iken, sulama sonrası bu oranın \%73.1'e yükseldiği, hububat ekim alanının ise \%31.7 düzeyinden $\% 15.2$ düzeyine gerilediği belirtilmiştir (Demir ve Yalçın, 2014).

\subsection{Hayvansal Üretim}

İncelenen işletmelerdeki hayvan sayıları ve hayvansal ürün değerleri Çizelge 7'de verilmiştir. 1. grupta sığı̀ sayısı ortalama 1.29 baş'tan 4.61 baş'a, koyun sayıs1 5.00 baş'tan 11,13 baş'a, keçi sayısı ise barajdan önce bulunmazken barajdan sonra 0.32 baş'a yükseldiği belirlenmiştir. 2. Grupta ise barajdan önce ortalama 0.67 baş sığır bulunurken barajdan sonra bu rakam 2.50 baş'a yükselmiş olup barajdan önce koyun ve keçi bulunmayan 2. gruptaki işletmelerde barajdan sonra sırasıyla 12.33 baş koyun ve 3.00 baş keçi olduğu tespit edilmiştir (Çizelge 7). 
Çizelge 6. İncelenen işletmelerde yetiştirilen ürünlerin ekim alanları (da)

\begin{tabular}{|c|c|c|c|c|}
\hline \multirow{2}{*}{ Ekim Alanı (da) } & \multicolumn{2}{|c|}{ Önce } & \multicolumn{2}{|c|}{ Sonra } \\
\hline & Grup 1 & Grup 2 & Grup 1 & Grup 2 \\
\hline Domates & 8.2 & 38.2 & 5.8 & 30.4 \\
\hline Buğday & 5.4 & 7.1 & 9.3 & 10.2 \\
\hline Arpa & 3.2 & 7.3 & 10.4 & 12.8 \\
\hline Yulaf & 2.3 & 1.2 & 7.9 & 8.4 \\
\hline Misır & - & 3.0 & 4.2 & 6.1 \\
\hline Patates & 2.7 & - & 3.1 & 3.2 \\
\hline Fasulye & & 3.8 & 4.1 & 6.7 \\
\hline Salatalık & 1.2 & 0.6 & 3.3 & 1.8 \\
\hline Patlican & - & - & 1.2 & - \\
\hline Fi & 4.6 & - & 8.8 & 9.6 \\
\hline Yonca & 2.5 & 4.2 & 10.7 & 10.5 \\
\hline Kabak & 2.6 & 0.3 & 4.3 & 1.1 \\
\hline Karpuz & 3.1 & 0.5 & 4.2 & 1.2 \\
\hline Soğan & 1.5 & - & 3.8 & - \\
\hline Biber & 2.6 & 4.6 & 1.1 & 6.6 \\
\hline Karnabahar & - & - & - & 2.2 \\
\hline Havuç & 3.3 & - & 2.8 & - \\
\hline Nadas (kuru) & 14.3 & 8.1 & 4.6 & 3.4 \\
\hline Elma & 1.3 & 4.6 & 3.2 & 2 \\
\hline Kiraz & 2.3 & 5.1 & 2.6 & 5 \\
\hline Armut & 0.8 & - & 0.6 & - \\
\hline Dut & 2.1 & 7.3 & 1.4 & 3.2 \\
\hline Toplam arazi & 64 & 95.9 & 97.4 & 124.4 \\
\hline
\end{tabular}

Çizelge 7. İncelenen işletmelerde ortalama hayvan sayıları

\begin{tabular}{lcccc}
\hline \multirow{2}{*}{ Hayvan sayıları } & \multicolumn{2}{c}{ Önce } & \multicolumn{2}{c}{ Sonra } \\
\cline { 2 - 5 } & Grup 1 & Grup 2 & Grup 1 & Grup 2 \\
\cline { 2 - 5 } Sığır sayısı (baş) & 1.29 & 0.67 & 4.61 & 2.50 \\
Koyun sayısı (baş) & 5.00 & - & 11.13 & 12.33 \\
Keçi sayısı (baş) &. &. & 0.32 & 3.00 \\
Tavuk sayısı (adet) & 1.77 & 0.67 & 0.81 & 0.67 \\
\hline
\end{tabular}

\subsection{Tarımsal Girdi Kullanımı}

1. gruptaki üreticilerin $\% 93.55$ 'i baraj sonrasında çiftlik gübresi kullanımında artış meydana geldiğini belirtirken, 2. gruptaki üreticilerde bu oran $\% 100.00$ 'dür. Kimyasal gübre kullanımının artış oranlarına göre, 1. gruptaki üreticilerin $\% 80.65$ ' $\mathrm{i}, 2$. gruptaki üreticilerin de $\% 90.91$ ' $\mathrm{i}$ baraj sonrasinda kimyasal gübre kullanımını artırmıştır. Üreticilerin zirai ilaç kullanımında da artış olduğu gözlemlenmektedir. 1. gruptaki üreticilerin \%77.42'sinin ve 2 . gruptaki üreticilerin \%72.73'ünün baraj sonrasında zirai ilaç kullanımını artırdıkları belirlenmiştir.

\subsection{Sulama Tekniği}

Baraj öncesinde 1. gruptaki üreticilerin \%100.00'ü, 2. gruptaki üreticilerin $\% 90.91$ 'i salma sulama sistemini kullanırken, baraj sonrasında 1. gruptaki üreticilerin $\% 87.80$ 'ninin, 2. gruptaki üreticilerin ise \%100.00'ının damla sulama sistemi kullandığ

(Özkay vd., 2008) çalışmalarında, tarımda sulama suyunun etkin olarak kullanılmamasından kaynaklı olarak toprak tuzluluğu, drenaj suyu gibi bazı çevresel sorunların oluşabileceğini tespit etmiştir. Aynı zamanda, sulama uygulamalarıyla, tarımsal üretim arttırılırken; kaynak kaybının yanı sıra, çevreye zarar verilmekte ve doğal dengenin bozulmasına neden olunmaktadır demişlerdir.

Orta Anadolu'da sulama randımanları salma sulama metotlarında $\% 55$ civarında iken yağmurlama sulamada \%75'ten fazladır (Balaban ve Ayyıldız, 1970; Çakmak, 1994; Topak, 1996). (Yurteri, 2011) çalışmasında, su uygulama randımanı son yıllarda giderek yaygınlaşan damla sulamada \%90'ın üzerine çıkmakta, bazı uygulamalarda \%100'e yaklaşabilmektedir demiştir. Su 
uygulama randımanının $\% \quad 50-55^{\prime}$ lerden $\% \quad 75^{\prime} \mathrm{e}$ yükseltilmesi, aynı miktar sulama suyu ile sulanabilecek alanın \% 50 artırılması demektir.

\subsection{Göç Durumu}

1. gruptaki üreticilerin baraj öncesinde şehirde yaşayan hanehalkı sayısı ortalama 0.06 kişi iken, baraj sonrasında bu rakam 0.77 kişiye yükseldiği tespit edilmiştir. 2. gruptaki üreticilerin ise baraj öncesinde şehirde yaşayan hanehalkı bulunmaz iken, baraj sonrasında ortalama 0.36 kişi olarak belirlenmiştir. Araştırma kapsamında 1. gruptaki üreticilerin köyde yaşayan hanehalkı sayısı baraj öncesinde ortalama 3.06 kişi iken, baraj sonrasında bu rakam ortalama 2.08 kişidir. 2. gruptaki üreticilerin ise, köydeki hanehalkı sayısı baraj öncesinde ortalama 2.91 kişi iken, baraj sonrasında 2.23 kişi olduğu tespit edilmiştir. Sulama ile gelir imkânlarının arttığı ve Ayaş ilçesinin Ankara'ya yakın olmasının etkisiyle de hanehalkları şehirde ikamet edip, hatta başka bir işte de çalışıp köydeki üretim faaliyetlerini sürdürmek gibi bir yapıyı geliştirmiştir.

(Büyükcangaz, 2003) çalışmasında, sulama projesinin uygulamaya geçirilmesine paralel olarak, her yıl hasat döneminde proje alanına geçici göç söz konusu olduğunu belirtmiştir.

\section{9. İstihdam Durumu}

1. gruptaki üretici hanehalklarının $\% 96.77$ 'si barajdan önce tarım sektöründe çalışırken, baraj sonrasında bu oran \%97.62 olarak saptanmıştır. 2. gruptaki üreticiler için bu oran ise, sırasıyla $\% 100.00$ ve \%74.19'dur. Araştırma sonuçlarına göre, baraj öncesinde 2. gruptaki üretici hanehalklarının hizmet sektöründe çalışmadığı belirlenmiştir. Ancak, barajdan sonra üretici hanehalklarının hizmet sektöründe çalışma oranın \%22.58'e yükseldiği tespit edilmiştir.

\subsection{Domates Maliyeti}

Domatesin birim maliyeti $(\mathrm{kg})$ her işletme grubunun verileri dikkate alınarak ayrı ayrı hesaplanmıştır. Araştırma kapsamında 1. gruptaki işletmelerde sulukuru şartlarda domates üretim faaliyetinde ekimden önce arazi iki defa sürülmektedir. Bölgede domateste üç defa gübreleme yapılmaktadır. Hasat el ile yapılır ve ürün paketlenip pazara taşınmaktadır. Araştırma alanındaki işletmelerde, dekara ortalama 1.790,23 adet fide, 0.29 lt zirai ilaç, $48.89 \mathrm{~kg}$ kimyasal gübre ve $2.804,32 \mathrm{~kg}$ hayvan gübresi kullanıldığı saptanmıştır (Çizelge 8).

İşletmelerde domates üretiminde kullanılan insan iş gücünün $\% 7.68$ 'i toprak hazırlığında, $\% 40.38$ 'i bakım işlerinde ve $\% 51.93$ 'ü ise hasat, paketleme ve pazara taşıma işlerinde kullanılmıştır. Toprak hazırlığ 1 için sarf edilen insan iş gücünün $\% 4.56$ 's1 birinci sürüm, $\% 2.85$ 'i ikileme ve $\% 92.59$ 'u ekim, dikim ve gübrelemede kullanılmıştır. Bakım işlerinde ise iş gücünün \%0.86's1 gübreleme, $\% 27.10$ 'u çapalama, $\% 71.71$ 'i sulama ve $\% 0.33$ 'ü tarımsal mücadelede gereklidir. Hasat ve pazara taşıma işlerinde gerekli olan iş gücünün $\% 89.29$ 'u hasatta, $\% 9.87$ 'si paketlemede ve \%0.84'ü pazara taşıma için sarf edilmektedir (Çizelge 8).

Her bir üretim işlemi için yapılan insan iş gücü, traktör çeki gücü ve kullanılan materyal masrafları ayrı ayrı hesaplanmış, masraflar toplamı üzerinden genel idare giderleri ve faiz tutarı bulunmuştur. Masraflar genel toplamı ise, domates üretim miktarına bölünmüştür. Bir dekar domates üretimi için 2.091,66 TL toplam masraf yapılmıştır. Masraflar toplamı içinde \%33.62 ile ekim ve dikim masrafları en fazla pay1 almış, sırasıyla hasat $\% 15.18$ ve sulama $\% 12.90$ oranı izlemiştir. İncelenen işletmelerde dekara ortalama domates verimi $3.844,56 \mathrm{~kg}$ ve $1 \mathrm{~kg}$ domates maliyeti 0.54 TL olarak hesaplanmıştır.

Araştırma kapsamında 2. gruptaki işletmelerde, dekara ortalama $1.810,71$ adet fide, 0.26 lt zirai ilaç, $43.53 \mathrm{~kg}$ kimyasal gübre ve $2.505,00 \mathrm{~kg}$ hayvan gübresi kullanıldığı saptanmıştır (Çizelge 8).

İşletmelerde domates üretiminde kullanılan insan iş gücünün $\% 7.41$ 'i toprak hazırlığı, $\% 40.73$ 'ü bakım işleri ve \%51.86'sı hasat, paketleme ve pazara taşıma işlerinde harcanmıştır. Toprak hazırlı̆̆ında sarf edilen insan iş gücünün $\% 4.78$ 'i birinci sürümde, $\% 2.81$ ' $\mathrm{i}$ ikilemede ve $\% 92.41$ 'i ekim, dikim ve gübrelemede kullanılmıştır. Bakım işlerinde ise iş gücünün \%0.90'1 gübreleme, $\% 23.78$ 'i çapalama, $\% 75.01$ 'i sulama ve $\% 0.31$ 'i tarımsal mücadelede gereklidir. Hasat ve pazara taşıma işlerinde gerekli olan iş gücünün $\% 89.58^{\prime} \mathrm{i}$ hasatta, $\% 9.53$ 'ü paketlemede ve $\% 0.89$ 'u pazara taşıma için sarf edilmiştir.

Bir dekar domates üretiminde 2.056,96 TL toplam masrafin yapıldığ tespit edilmiş olup, masraflar toplamı içinde \%34.86 ile ekim ve dikim masrafları en fazla payı alırken, bunu sirasiyla hasat (\%14.65) ve sulama (\%13.18) izlemiştir. İncelenen işletmelerde dekara ortalama domates verimi $4.142,86 \mathrm{~kg}$ ve $1 \mathrm{~kg}$ domates maliyeti 0.50 TL olarak hesaplanmıştır (Çizelge 9).

Ayaş ve Nallıhan ilçelerinde yapılan çalışmada, Ayaş ilçesinde bir dekar domates yetiştiriciliği için yapilan toplam masraflar $280.49 \mathrm{TL}$ ve bir $\mathrm{kg}$ domates maliyeti sırasıyla 0.06 TL olarak tespit edilmiştir (Demirci ve ark., 2005).

Ankara ili Beypazarı ilçesinde yapılan çalışmada, organik ve geleneksel olarak yapılan domates üretiminin ekonomik analizi incelenmiş, araştırma sonuçlarına göre geleneksel olarak üretilen $1 \mathrm{~kg}$ domatesin maliyeti 0.25 TL olarak tespit edilmiştir (Erkoyuncu, 2008).

Ankara'da domates yetiştiren işletmelerin ekonomik analizi incelenmiş; tarla döneminde işletmelerde 1 da domates yetiştiriciliği için yapılan toplam masraflar Ayaş ilçesi için 280.45 TL, işletmelerde ortalama domates verimi Ayaş ilçesinde $4.712 \mathrm{~kg} / \mathrm{da}$ olarak hesaplamıştır (Tatlıdil vd., 2003). 
Çizelge 8. İncelenen işletmelerde 1. gruptaki üreticilerin domates üretim maliyeti

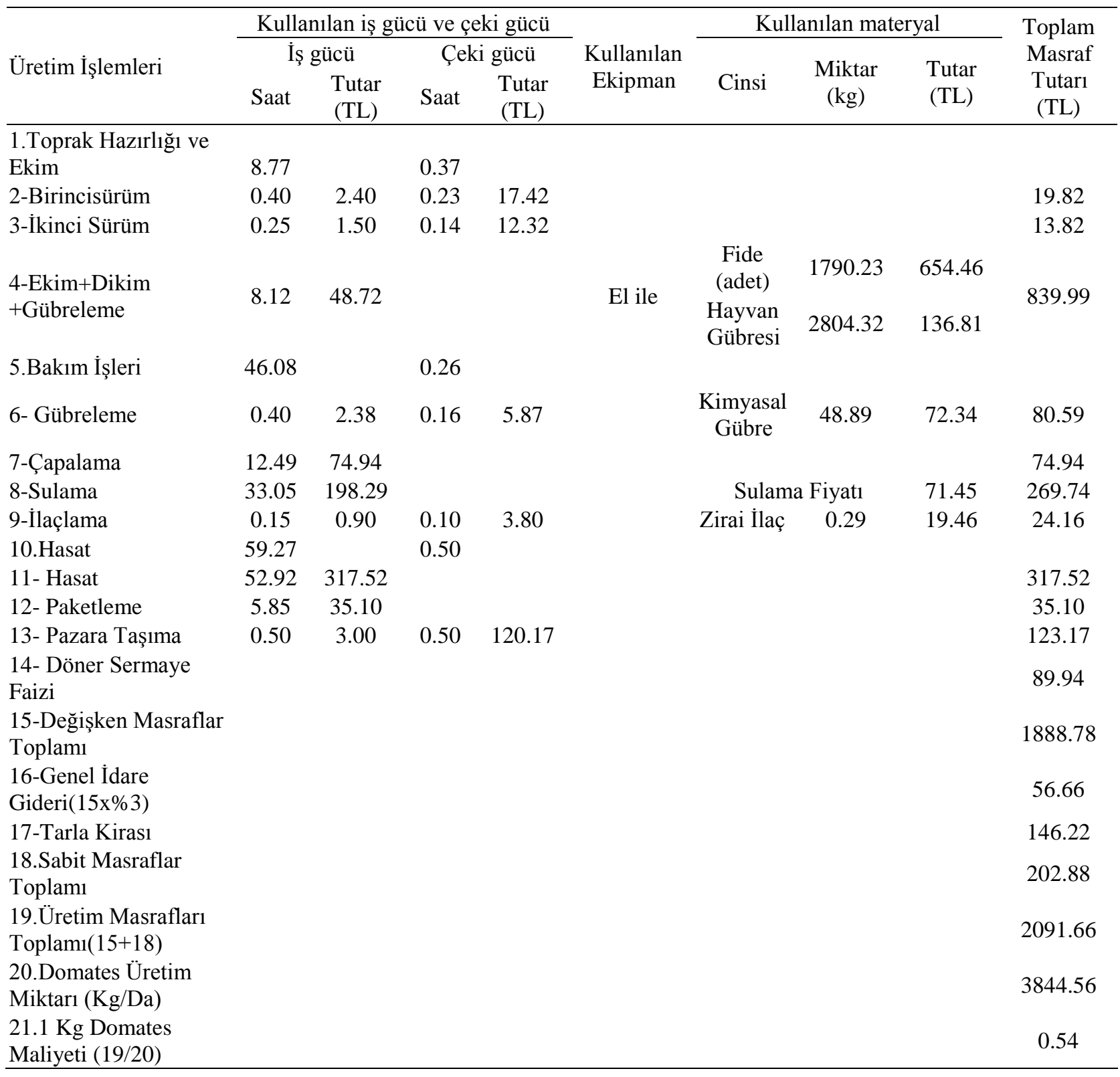

\section{Sonuçlar}

İncelenen işletmelerde baraj yapımının tarımsal sulamanın kullanımının etkinliğini arttırmasının yanı sıra üreticilerin üretim deseninde de değiş̧ikliği gittiği tespit edilmiştir. Araştırma bölgesi olarak belirlenen Ankara ili Ayaş ilçesinde yoğun olarak domates üretimi yapılmaktadır. Araştırma sonuçlarına göre üreticilerin, baraj sonrasında domates ekim alanlarında küçülmeye giderek, yem bitkileri ekim alanlarının arttığı belirlenmiştir. $\mathrm{Bu}$ durumun sebebi olarak, domates üretiminde verimin yeterli seviye de olmaması ve ürün satışı konusunda yaşanan sıkıntılar olarak belirtilebilir. İncelenen işletmelerde baraj sonrasında çiftlik gübresi, kimyasal gübre ve zirai ilaç kullanımının arttığ 1 tespit edilmiştir. Domates maliyetleri 1 ve 2 . gruplar için ayrı ayrı hesaplanmıs olup sırasıyla $0.54 \mathrm{TL} / \mathrm{Kg}$ ve 0.50 TL/kg'dır. Özellikle, fiğ ve yonca ekim alanlarının artması hayvancılığa bir yönelimin olduğunu işaret etmekte olup, sığır, koyun ve keçi sayısında önemli artışların olduğu dikkat çekmektedir.

Tarımda sulama etkinliğinin artırılması ile üreticilerin üretim deseninde değişikliğe gittiği tespit edilmiştir. Üreticilerin baraj sonrasında, hem ekim alanlarında yem bitkilerine yönelimi, hem de işletmelerdeki hayvan sayılarındaki artış göz önüne alındığında, hayvancılığa yönelim olduğu belirtilebilir. Baraj öncesinde üreticilerin büyük bir çoğunluğu salma sulama sistemini kullanırken, baraj sonrasında damla sulama sistemine geçildiği gözlenmiştir. Yani, üreticiler, sulamadan daha etkin bir şekilde yararlanmaya başlamıştır. Baraj sonrasında, şehirde yaşayan 
hanehalkında artış gözlenmiştir. Ayaş ilçesinin Ankara’ya yakınlığı burada önemli bir faktör olmuştur.

Ayaş ilçesinin eğitim, nüfus ve Ankara iline yakınlığı gibi güçlü yönleri bir arada değerlendirildiğinde, sulamanın katkısı ayrıca etkin ve verimli damla sulama yöntemlerinin kullanılması sayesinde, üretim deseni ihtiyaçlara binaen çeşitlendirilip yörenin istihdam ve tarımsal geliri artırılabilir. Ayaş ilçesinin turizm alt yapısı da mevcut olduğundan, yöreye ait bitkisel ve hayvansal ürünlerin satışı ile kalkınma hızlandırılabilir.

Çizelge 9. İncelenen işletmelerde 2. gruptaki işletmelerin domates üretim maliyeti

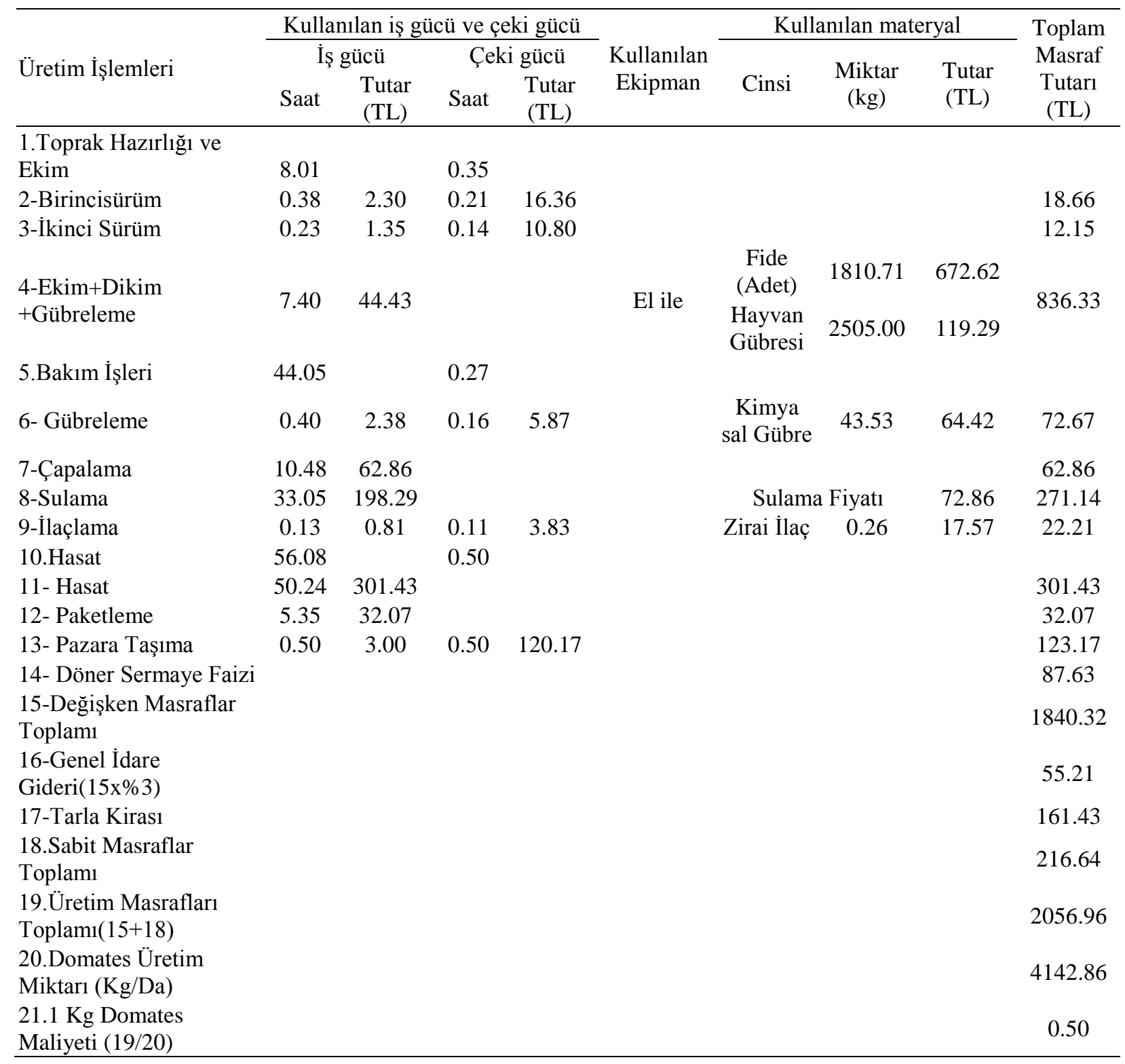

\section{Teşekkür}

$\mathrm{Bu}$ çalışma, Ankara Üniversitesi BAP tarafından desteklenmiş ve tamamlanmış bir projedir.

\section{Kaynaklar}

Ankaraka, 2015. Ankara kalkınma ajansı, http://www.ankaraka.org.tr (Erişim tarihi: 11 Haziran 2018).

Balaban, A., Ayyıldı, M., 1970. Orta anadolu sulamalarında tarla sulama sandımanı üzerinde bir araştırma. Ankara Üniversitesi Ziraat Fakültesi Y1llığı, Ankara Üniversitesi Basımevi, Ankara.

Büyükcangaz, H., 2003. Sulama projelerinin çevresel etki değerlendirmesi (çed) ve Bursa-Mustafa Kemal paşa sulama projesi örneği. KSÜ Fen ve Mühendislik Dergisi, 6: 108-116.

Çakmak, B., 1994. Konya-çumra sulamasında su dağıtım ve kullanım etkinliği. Doktora Tezi (Yayınlanmamış). Ankara Üniversitesi Fen Bilimleri Enstitüsü, 120s, Ankara. 
Çakmak, B., Polat, H.E., Kendirli, B., Gökalp, Z., 2009. Evaluation of Irrigation Performance of Asartepe Irrigation Association: A Case Study From Turkey. Akdeniz Üniv.Ziraat Fakültesi Dergisi, 22(1): 1-8.

Demir, O., Demir, N., Tekin, M., Yalçın, Z., 2014. Erzurum daphan ovası sulama yatırımının tarımsal üretim üzerine etkileri. ÇOMÜ Ziraat Fakültesi Dergisi, 2(2): 97-103.

Demirci, F., Erdoğan, C., Tatlıdil, F., 2005. Ankara ili ayaş ve nallıhan ilçelerinde domates üretim alanlarında zirai mücadele uygulamaları. Tarım Bilimleri Dergisi, 11: 422-427.

Doak, M., Parminter, I., Horgan, G., Monk, R., Elliot, G., 2004.The economic value of irrigation in new zealand. MAF Tech. Pap. No: 04/01.ISBN No: 0478-07798-X.

Erkoyuncu, C. 2008. Ankara ili beypazarı ilçesinde organik ve geleneksel olarak yapılan domates yetiştiriciliğinin karşılaştırmalı ekonomik analizi. Yüksek Lisans Tezi. Ankara Üniversitesi Fen Bilimleri Enstitüsü, 114s, Ankara.

Kaltu, S., Güneş, E., 2010. Mısırda (zea mays L.) farklı sulama sistemlerinin verim ve gelir üzerine etkisi. Tarım Bilimleri Dergisi, 3: 27-31.

Koç, A., Güner, Ü., 2005. Reassessment of existing irrigation projects with fao criteria: tavas plain example. Dumlupınar Üniversitesi Fen Bilimleri Enstitü Dergisi, 9: 93-106.

Mudima, K., 2002. Socio-economic impact of small holder irrigation development in zimbabwe: A case study of five successful irrigation schemes. Private Irrigation in sub-Saharan Africa.

Özkay, F., Taş, İ., Çelik, A., 2008. Sulama projelerinin çevresel etkileri. TMMOB 2. Su Politikaları Kongresi, Cilt 2, 501-508, 20-22 Mart, Ankara.

Saunders, C., Saunders, J., 2012. The economic value of potential irrigation in Canterbury. Lincoln University.

Sönmez, M.E., 2011. Barajların mekan üzerindeki olumsuz etkileri ve Türkiye'den örnekler. Gaziantep University Journal of Social Sciences, 11.

Tatlıdil, F., Kıral, T., Güneş, E., Demir, K., Gündoğmuş, E., Fidan, H., Demirci, F., Erdoğan, C., Aktürk, D., 2003. Ankara ili'nde domateste hasat öncesi ve hasat sırasında oluşan ürün kayıplarının ekonomik analizi. Proje no:TARP-2387. Ankara.

Topak, R., 1996. Konya çumra ovasındaki yağmurlama sulamalarında uygulama sorunları. Doktora Tezi. Selçuk Üniversitesi Fen Bilimleri Enstitüsü, 33s, Konya.

Yamane, T., 2001. Temel örnekleme yöntemleri, İkinci Baskı, Literatür Yayınları, $528 \mathrm{~s}$, İstanbul.

Yıldırım, A., 2006. Karakaya barajı ve doğal çevre etkileri. Dicle Üniversitesi Ziya Gökalp Eğitim Fakültesi Dergisi, 6: 32-39.

Yurteri, Y.D., 2011. Konya-kadınhanı-kolukısa kasabası sulama kooperatifi çiftçilerinin sulama işletmeciliği sorunları ve çözüm önerileri. Yüksek Lisans Tezi. Selçuk Üniversitesi Fen Bilimleri Enstitüsü, 47s, Konya. 